\title{
7 自由度油圧義手（プロトタイプーI）
}

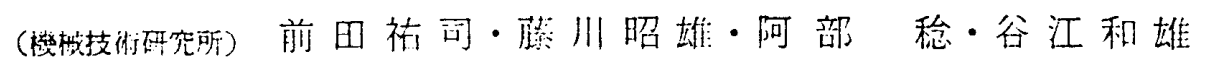
大野武房・谷和男・本田富士雄 (早稫田大学) 稻永卓二・山中敏史・加藤一郎

\section{1.はじめに}

社会梅造の急激な発達は国民の生活向上, 便利さな ど多くの面で恩恵を与えているか，一方では公害や労 働災害，交通災害を引き起している。このような災害 による身体障害者の数は年々增加の一途をたどってい る.

最近になって身体障害者のリハビリテーションとい らことが叫ばれるよらになり義肢, 装具の面でも技術 開発が行なわれるよらになった，现在までの動力義手 に閉する開発研究例は，身体の部位による種類では前 腕莪手，上腕義手がはとんどで全腕蒰手は非常に少な く,このタイプの莪手の開発が望まれている．また，駆 動源の種類では電気式による㼁手が最も多く，てれに

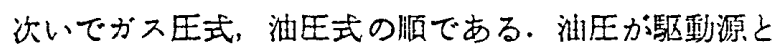
してあまり使用されなかった理由は，軽昷で小型のポ ンプやフクチニニータがなかったことによると思るれ る. しかし，油式は重量に対する出力比が大きく， 低速で大きなパローを得ることができる。

筀者らは，開発例の少ない高位欠損者を対象とした 多自由度義手の実用化を最終目標として，

（1）人間の上肢の聯能になるべく近い機能をもつ燨 手の自由度模成はいかにあるべきか，

（2）将来，人間か容易に制御を行於い5る義手の自 由度配鮎はいかにあるべきか，

（3）要求される機能は全重量との関係においていか にあるべきか，

を確認するため， 7 自由度油王義手（プロトタイプー I）を設計, 試作した。

なお，本義手は将来筋電による制御を想定してい 3.

\section{2. 基本的な設計方針}

\section{1 自由度数}

助力義手を開発する苆合, 肩や腕, 手にどの程度の 自由度を持たせるかが義手の機能性を左右する，人問 の肩から指先までの構造モデルとして Morecki らは 27の自由度を示したか，このよらな自由度をもつ義手 を作ることは，フクチニエータの大きさや重昷の点で 现在では不可能であるばかりでなく，人間の制御能力 から考えても非现实的である. したがって，自由度数 は人問の腕の怔作となるべく似た项作ができる必垩最 小限の自由度を考虑するものとした人間の腕の機能 は，上腕と前腕で三次元空問での手しの位置ぎあを行 ない，前腕で手苗の姿勢ぎめとハンドリングを行なら と考えれば，局に三次元空間内での位置ぎめを行なう 3 自由度と时より先に姿勢泛定の 3 自由度をもたせれ ばよいことになる。手先は，とのような掘み怔作を行 ならかによって自由度の数が変ってくるが，単に指で 対象物を持つことを考えれば拇指と他の 4 指が対象物 に通応した動作をし把握すればよいと思われる。以上 のことから上腕に 3 ，前腕に 3 および指操作に 1 の合 計 7 自由度をもたせ一応の機能をるつようにした。

\section{2 動 力 源}

荻手の動力源は電気式，ガス正式と油王式の 3 種類 およびそれらの組合せが考えられる。蕓気式はバッテ リーおよびアクチニニータの小型軽量化, 応答性, 効 率なとの研究で一応のピークに達していると思われ る. また，出力の点で不满足である.ガス式式，油臣 式は，電気式に比較して研究の余地が残されている。 とくに低速で大きな出力の得られる油区式は，アクチ 
表 I FRP仕梯

\begin{tabular}{|c|c|c|c|c|}
\hline 基 & 材 & \multicolumn{3}{|c|}{ ガラスクロス } \\
\hline 結 & 梌 & \multicolumn{3}{|c|}{ エボキシ } \\
\hline 比 & 重 & \multicolumn{3}{|l|}{1.9} \\
\hline 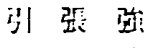 & さ & \multicolumn{3}{|c|}{$31.5 \mathrm{~kg} / \mathrm{mm}^{2}$} \\
\hline 曲 代 色: & $己$ & \multicolumn{3}{|c|}{$50.2 \mathrm{~kg} / \mathrm{mm}^{2}$} \\
\hline 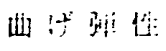 & 潇 & \multicolumn{3}{|c|}{$2000 \mathrm{~kg} \cdot \mathrm{mm}^{2}$} \\
\hline 吺 & 污 & \multicolumn{3}{|c|}{$0.04 \% \circ \quad 23 \mathrm{C} / 24 \mathrm{~h}$} \\
\hline 酎 & 任 & & 初期仵 & 48時閪倿 \\
\hline 外 锂 变 & 化 & & & 变化圤L \\
\hline 曲 け望: & $己$ & $\left(m^{2}\right)$ & $36 \sim 40$ & $35 \sim 38$ \\
\hline 曲げ㤝出 & 事 & $\left.m^{2}\right)$ & $1900 \sim 2100$ & $1990 \sim 2040$ \\
\hline
\end{tabular}
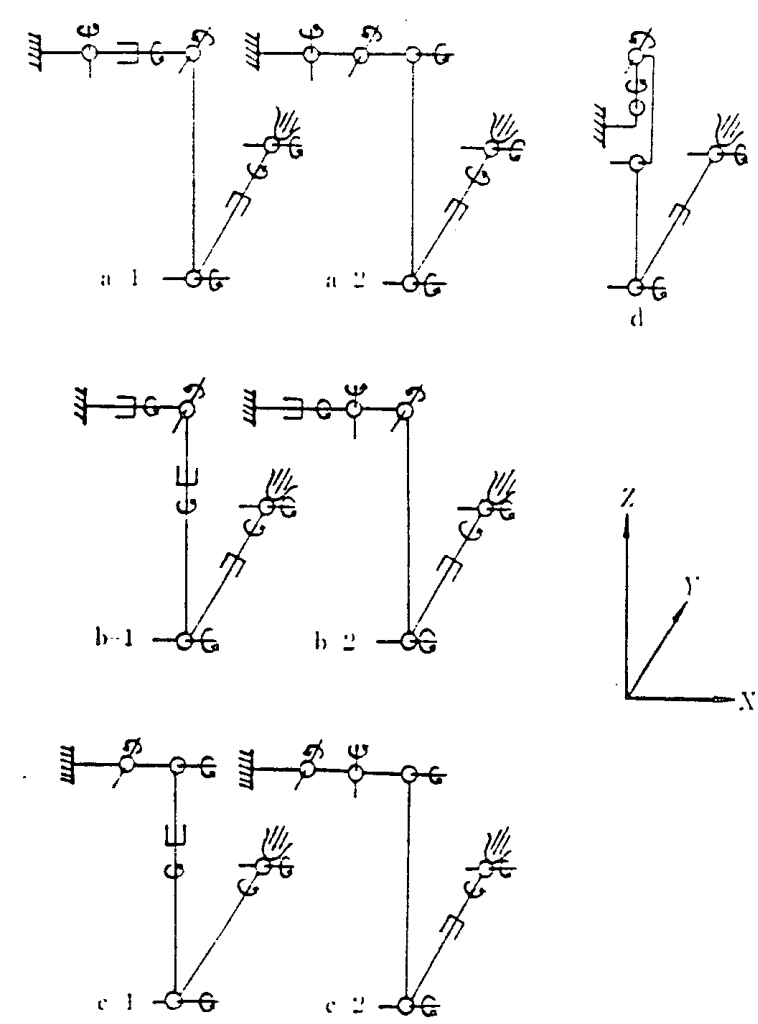

图 1 白由度の配详法

ニエータの開発によって今後の発展が期待されるので 油压方式を彩用した。

\section{3 アクチュエータ}

油王式のフクチニニータは直動型および回転型があ る. 回転型アクチニエータのらちのロータリサーボフ クチニニータ（RSA）は、アクチュニータの入力軸 が流量制御弁になっているので，直動型や他の回転型 アクチニエータのよらにンレノイド式流量制御弁や方 向制御弁が必要でなく，回路が簡略化できる。むた， 出力回転角がメカカルフィードハック方式なので回 転角は高い精度が得られ，電気一油王变換も容易なの でRSAを採用した。

\section{4 材管}

義手の材料よして重要なことは，軽量で耐久性があ

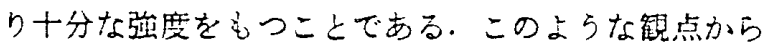

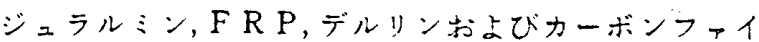
バーなどを考滤した，人間の骨:椙当する莪手の梁に は，主にFR P (泰1に仕㯒を示子)，ジラシミンを 使用し，入力軸駆動の后動機棈の一部にデルリン製の 朄車を採用した。

\section{5 油路}

通常はパイプによる配管を行なうが，外観上好まし くない上に限られた空問内での配管はかなり無理があ

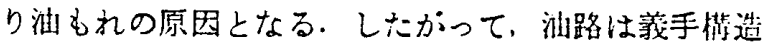
体の内部を通しR S A 自体を分配器として利用し油路 の簡略化を図った。

\section{3. 義手の駆動システム}

\section{1 自由度配置の険討}

人間の複雑な腕の動きを7個の自由度で置换えるこ とは，たいんん困萪である，人間の肩に相当するボー ルジョイント(完全なボールジョイントではないが）の 動きを平現できるてクチニニータは見当らない。そこ

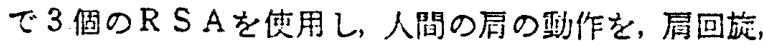
局上下および肩前後回転で再现することにした(洴)。 さらに，将来の觔電信号による制御に備えて，制御し やすい上らに自由度の配直を行なら必要がある。图 1 は，7佪の自由度のらち指操作を除いた腕の 6 自由度 の配置を示したもので，时から手先の自由度の配置は すべて共通である、a-1，a-2 は局回旋が同位圆に あるが局前後, 肩上下が翼なっている. b-1， b-2 は肩前後は同位眉にあるが肩回旋，层上下が異なって いる. c-1，c-2 は肩上下は同位置にあるが肩回旋 肩前後は異なっている，また，人間がある目標物に向 かって手を伸ばす(リーチニーション)場合, 肩と时お よび手首は同一平面内で汪ぼ動作が行なわれている。 耊手の場合，図2のように方向と位睓の決定を行なえ ばよいことになる。したがって，三次元の位四ぎる 二次元平面内での制御に罳き换えることができるので 制御が容易になる。そのための自由度配圆としては， 肩の前後回転軸と肘の回転軸が方向ぎめにおける他の 

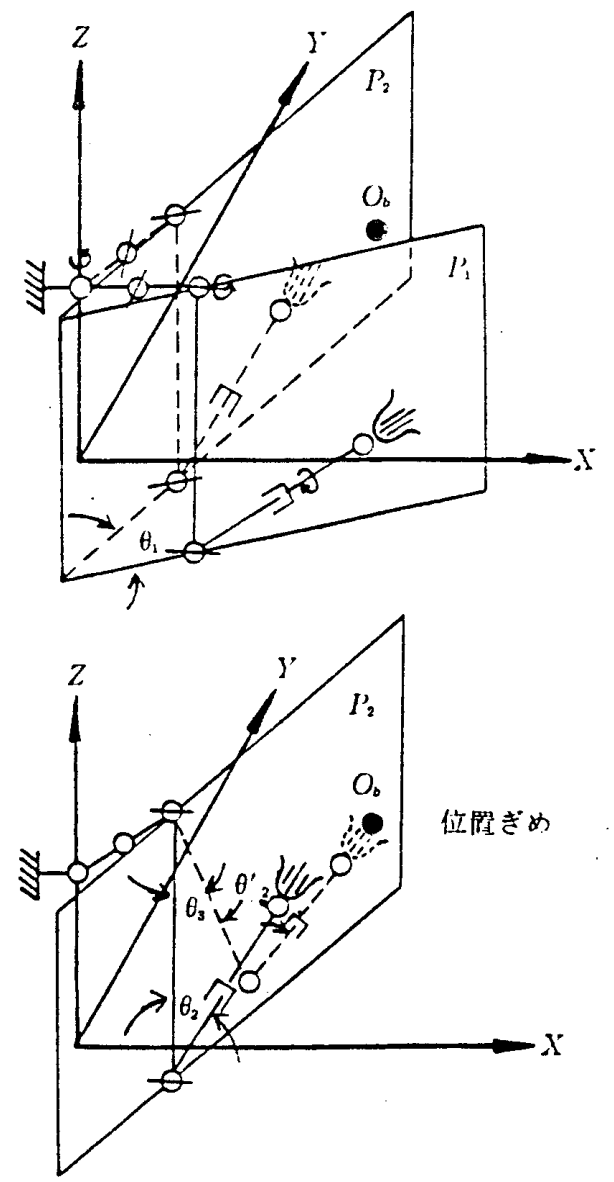

因2リーチモーション

自由度の侽きに関保なく常に平行を保つ必要がある。 この条件を满足するのは る. aー2，c-2かi自由度配直としては上いか，動作 状態での外観の点でaー2の变形としてdを採用し た。

\section{2 アクチュエータの配置}

ブロトタイブーIのフクチニニータ配固は，自由度
(自由度西保)

(K. S. A Riti)
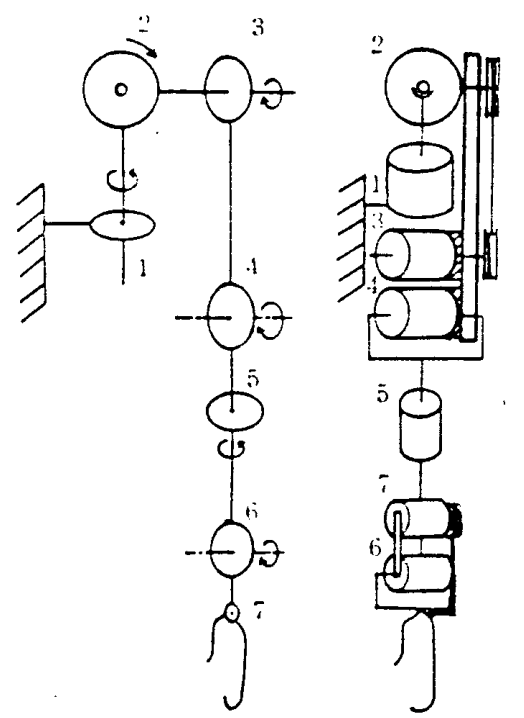

1. 角回族

剧上下

3. 有前後

4. 肘惟曲保

万.

i. 乎苗背屈

7. 指譄俳

因 3 白由度眍㩆とRSA配活

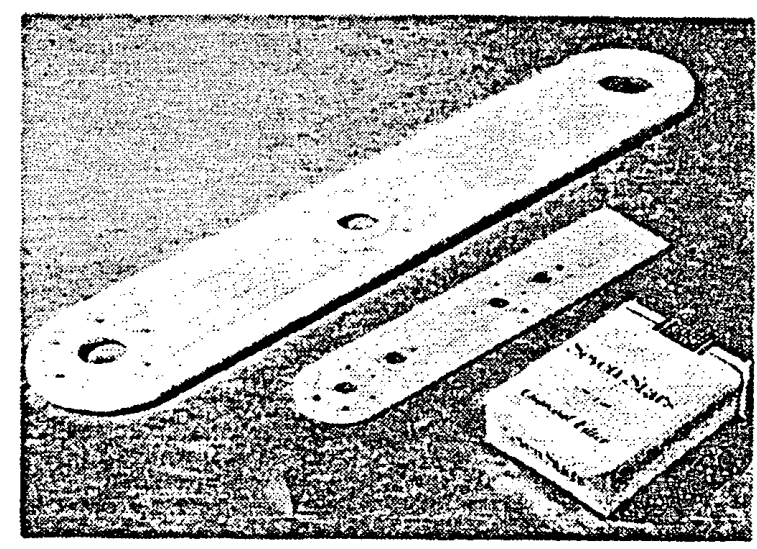

図 4 FRP梁内部の油路

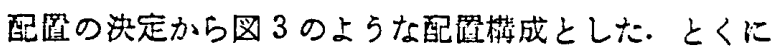
期力損失を防ぐためにフクチニニータを肩に近い配置 とした，制御を容易にするために肩の 3 自由度の回龒

表 2 RSA仕栚

\begin{tabular}{|c|c|c|c|c|c|c|c|c|c|c|}
\hline \multirow{2}{*}{ 珄能 } & 形 & \multirow{2}{*}{ 摇 } & \multirow{2}{*}{$\begin{array}{l}\text { 酎 角 } \\
\text { 革 }\end{array}$} & \multirow{2}{*}{$\begin{array}{c}\text { 出カトルク } \\
\mathrm{kgm}\end{array}$} & \multirow[t]{2}{*}{ 重 } & \multirow[b]{2}{*}{$\mathrm{g}$} & \multirow{2}{*}{$\begin{array}{c}\text { 理論流油量 } \\
\mathrm{cc} / \mathrm{rad}\end{array}$} & \multicolumn{3}{|c|}{ 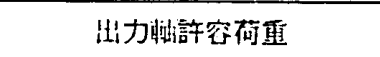 } \\
\hline & 2 & & & & & & & スラスト $\mathrm{k}$ & ラジフル & $\mathrm{kg}$ \\
\hline 局回旋 & MB15 & & 280 & 0.64 & & 387 & 2. 72 & 2 & & 38 \\
\hline 用上下 & M B30 & & 280 & 1.28 & & 650 & 5.32 & 2 & & 48 \\
\hline 届访後 & M B30 & & 280 & 1.28 & & 610 & 5.32 & 2 & & 48 \\
\hline 肘 & MB15 & & 280 & 0.64 & & 380 & 2. 72 & 2 & & 38 \\
\hline 前㯊回内外 & M B 04 & & 280 & 0.17 & & 155 & 0.73 & 2 & & 23 \\
\hline 指 操 作 & MA04 & & 100 & 0.17 & & 110 & 0.80 & 1 & & 16 \\
\hline 手首背屈 & MA04 & & 100 & 0.17 & & 110 & 0.80 & 1 & & 16 \\
\hline
\end{tabular}

出カトルクは $30 \mathrm{~kg} / \mathrm{cm}^{2}$ の時のトルク 


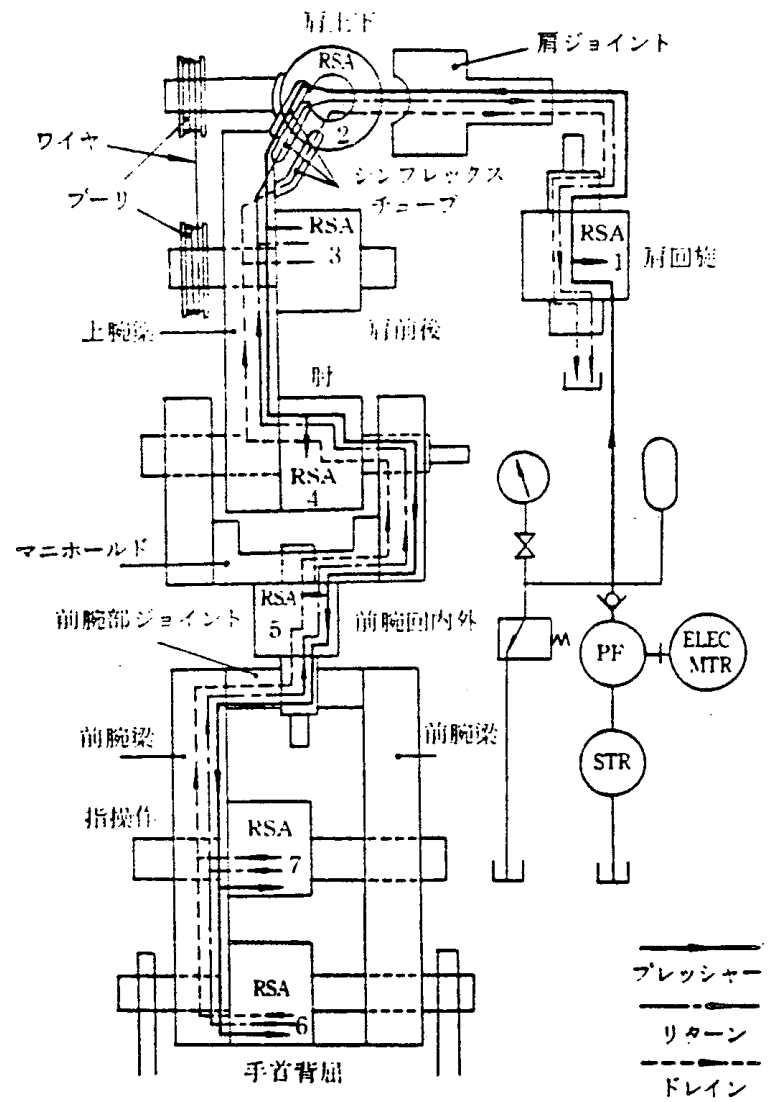

图 5 油王回 路

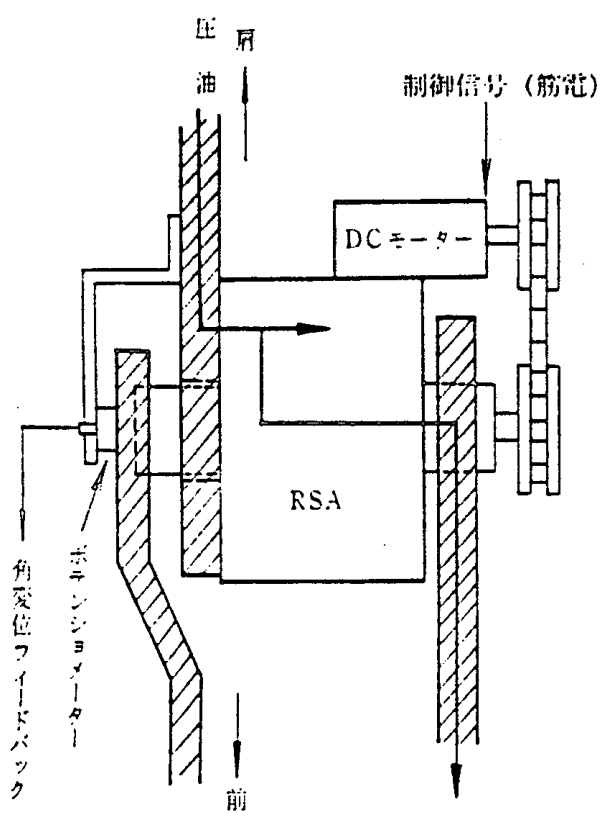

5

因6 油压回路の分岐法お上び霆気回路

中心軸は一点で交わるよ5に設計し，外観を人間の腕 に似せるため肩の 3 個のアクチュニータのらち，局前 後のアクチニニータを上腕の中間位固に配苴した。

\section{3 R S Aの選定}

7 自由度の各自由度位固にどのようなR S A を採用 するかは，R S A の出力，寸法，重量および可動角な どか問題となる。ブロトタイブーIでは，必要なトル クの計算を行ない可動角を検討し表 2 のようにR S A の選定を行なった。

\section{4 油王回路の構成}

油王回路を簡略化するとともに油のもれを防ぐこと は，油王式義手の条件である．㼁手の油正回路では梁 とアクチュニータ，梁と梁なとに相対運動があり油王 回路の構成を困難にする。まむ，油路分㞳形態をどの よらにするかも問題となる。プロトタイブーIでは, 油路を義手槽造体の内部に設け油のもれを防止するよ らに製作し，油王分配はRSAまたは梁の内部で行な ら上5にした图 4 は，FR P 梁内部の油路の様子を示 したものである.FRPの板（上腕：板厚 $5 \mathrm{~mm}$, 前 腕：板厚 $3 \mathrm{~mm}$ ）にエンドミルで必要な油路の大きさ の满を掘り， $2 \mathrm{~mm}$ の板をかぶせフラルダイトで接着 した. 3 本の溝はプレッシャー、リターンおよびドレ インの回路である。局上下と肩前後間の油路は，梏造 上義手の梁内部に設けることは困難で，梁の外部に出 しシンフレックスチニーブを用いた．四５は，プロト

表 3 DCモータ，減速機，ボテンショメータ仕梾

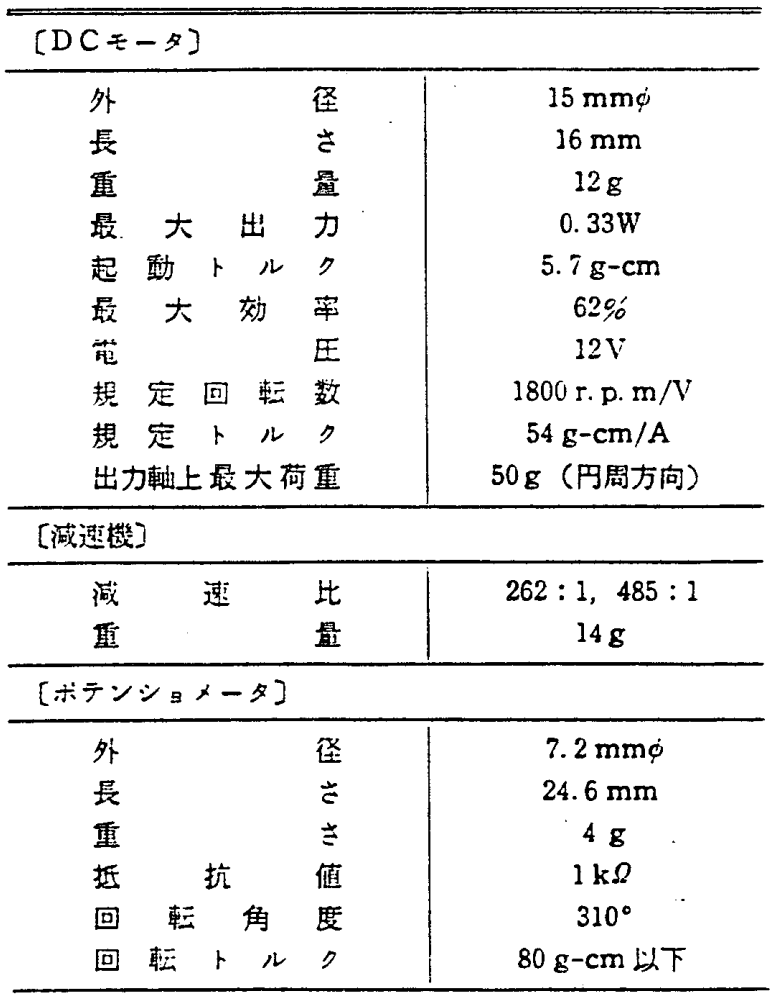




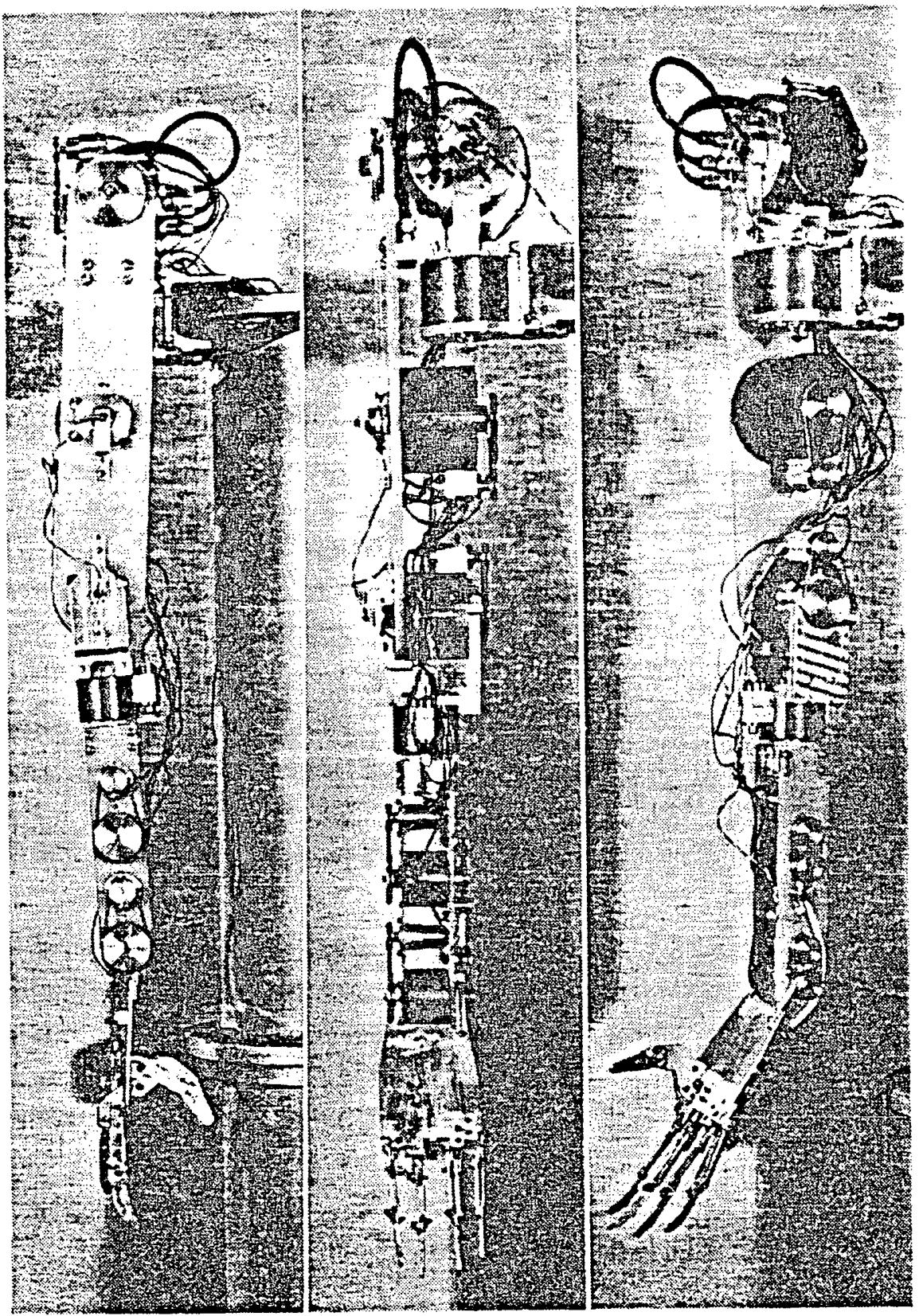

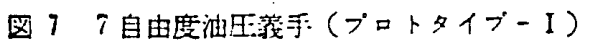

タイプーIの油因回路困である．四6は，RSAの内 部での油正分配を示した图で时に採用した回路例であ る.屏から梁の内部を王送されてきた油は，RSAを

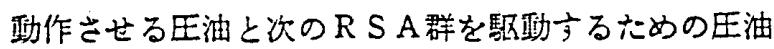
として，出力軸の内部に設於た油路を通って，次の梁 内部の油路に王送される。

\section{5 電気回路の構成}

義手を操作する場台，R S A の入力軸に制御信号を 送らなければならないプロトタイプーIでは，雷気

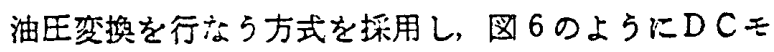
一タを使用してベルト駆動あるいは紫平駆動（デルリ
ン製）により，RＳAの入力韩駆動を行なった．出力 軸の角変位は，ポテンショメータにより柃出されフィ

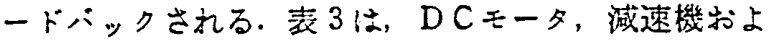
びポテンショメータの仕様を示す。

\section{4. 義手の構造}

試作した莪手（プロトタイブーI）の写真を図 $7 に$ 示す.

\section{1 肩}

因 8 は局回旋，局上下の篟造を立体的に示したもの 


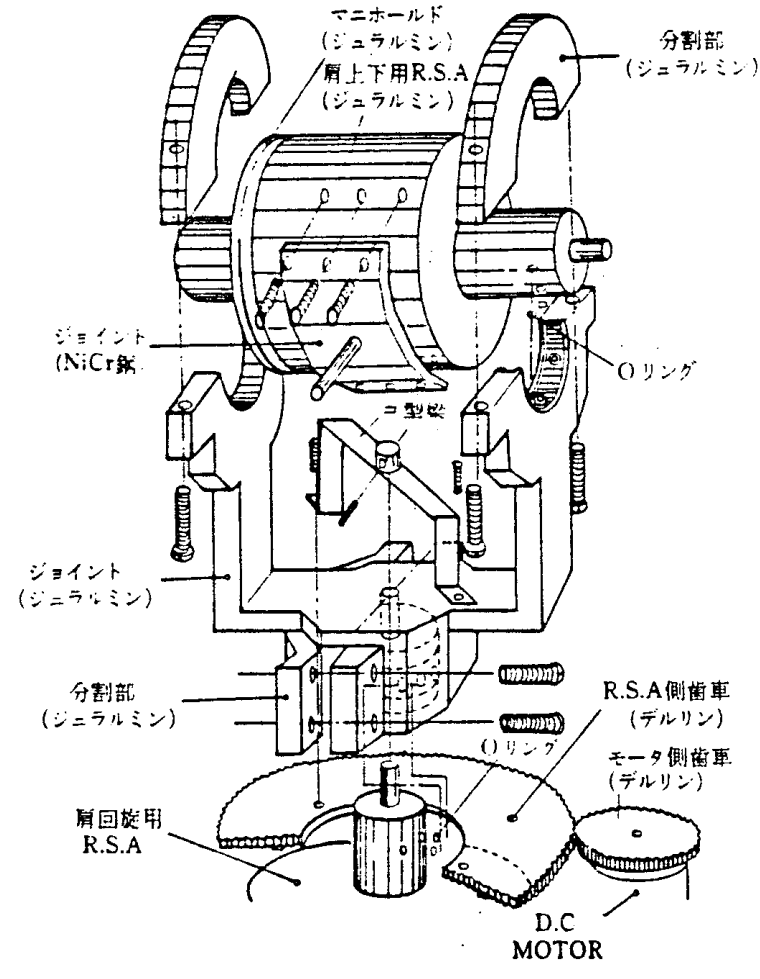

因8屏の構造

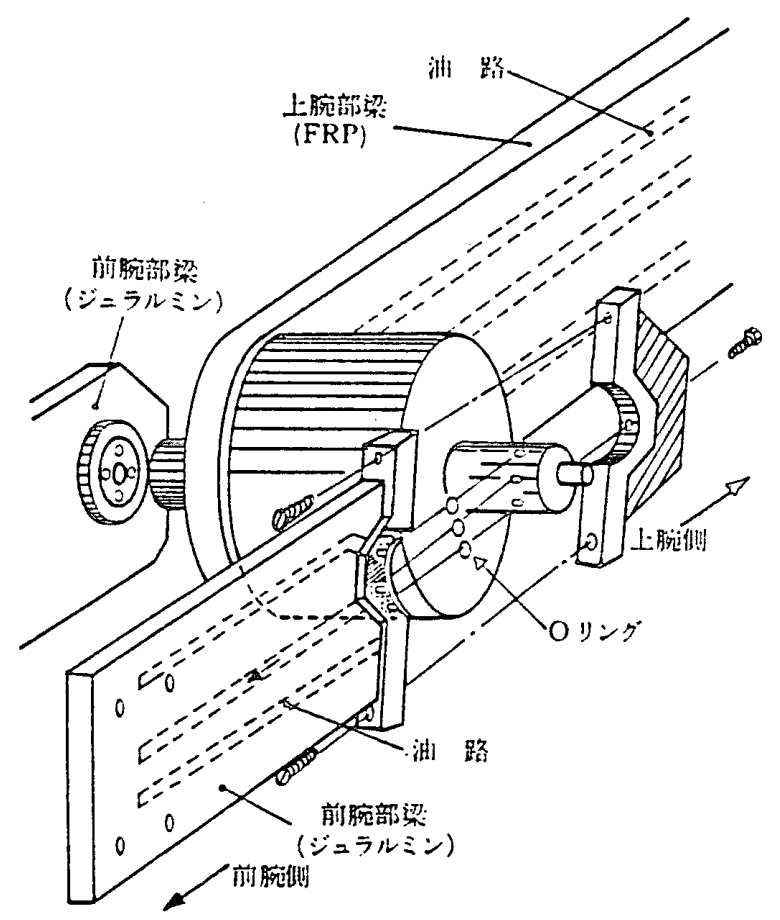

図 9 时 の構 造

である. 屃回旋の回転中心軸と肩上下の回転中心軸 は，交丒するよらに製作されている。肩回旋用R S A の入力軸側出力軸にジニラルミンで製作したジョイン トの下部の分割部がネジよって箱めつけられるよう になっている．分割部のジョイント側本体には，肩回
旋用 R S A の入力軸側出力軸から次のR S A に供紿さ れる油路が設方てあり，Oリングのための來ぐりが

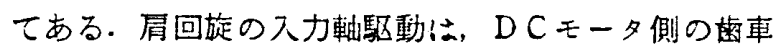
から R S A 側の画車に伝達され，局上下のR S ョイントの間に示した入力軘駆勳用の梁によって回䎐 遇動汃法達される．入力䩜駆動用の梁上出力軸に固定 したジョイント部は，四転運動こしては追良するので 接触することはない。

ショイント部の内部を通った油は，肩上下のR S A の出力軸の油路に入り，肩上下のR S A の駆動と肩前 後以下のR S A に油を供給なる、ジョイント部の油路 の匤油出口は，Oシングのための來ぐりがしてある。 局回旋のR S A は八ウジンク固定で軸が回転方るが, 肩上下のR SAはショィントに軸を固定しハウシンング か回転する．局前後以降のR S A に供紿される区油 はこここで首上下のR S Aを作動する区油と分岐して。 局上下R S A の入力軸とは反対のハウジンクにとりつ けたマニホールドからシンフレックスチニーブを通 ク，FR P の梁内部に入る。

肩上下のR S A のハウジング外周面にとりつけられ たニッケルクロム鈵材のジョイントの軸が，肩前後の 回転中心粙である．局前後は，上腕にとりつけたR S Aよりワイヤで駆動される。制御性を考虑して肩回 旋, 肩上下および局前後の R S A 回転中心軸法，一点 で交わるよらに製作されている。

\section{2 时}

因 9 は，肘の耤造を示したもので局から肘までの骨 に相当する FR P の梁に时のRSA が固定されてい る。油はFR P 梁内部の油路を通り，RSAハウシ ングの端面に設けた油路に入り軸を駆動する，R S A の内部で分忮した压油は，前腕回内外以降のR S At 駆動するために，出力軸内部に設けた油路を通り，入 力軸側の出力軸外周面よりジニラルミン製の梁内部人 送られる。

\section{3 前腕回内外}

前腕回内外の模造を図10に示す。四10の左上之左下 のジラルミン製の梁か，时の出力軸に固定されてい て.その二つの梁に前腕回内外用のマニホールドが固 定され，RSAがとりつけられる，RSA入力側出力 軸には，前腕部のF R P を固定するためのジュラルミ ン製の分割したジョイントがとりつけられて，2枚の 


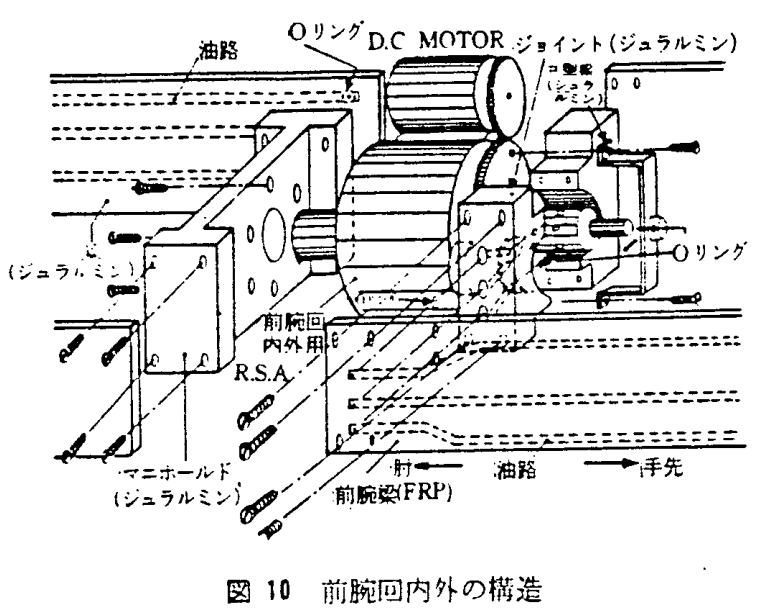

F R P の梁はネジによって固定される.

油路法前腕回内外のマニホールドの内部を通りR S $\mathrm{A}$ の駆動と手首の背屈, 指操作のR S A に分配され ろ. 手首の背屈と指操作のための油路は，前腕回内外 R S A の入力軸側の出力軸から分割したジニラルミン 製のショィントを通り，FR P 梁の内部の油路に入 る.

入力軸の駆動系は，R S Aの本体に固定したDCモ

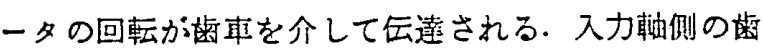
車はジララルミン製のコ型をした梁によって, 軸に固 定するよらになっている. ポテンショメータは四に示 していないが，マニホールド侧の出力軸端にあり，信 号をつィードィックする.

以上，局から前腕に使用した部品を図11に示す。

\section{4 手 裳 部}

手掌部の仕粎決定については，人問の日常生活に必 要な動作を以下のように列挙し決定した。 (a) ホの入っているコッブを持つ.

(b) ビールをコップにそそぐ。

(c) 球状の物体を安定よく握る.

(d) 絵を画く.

(e) 荷物をさげて持つ.

（f）圈いてある鉛䈋程度の太さの物を拾い上げる. 以上の動作をできるだけ満足させることと，人間の 手先に似た形および指の動きに重点を置いた。

人間の指はとのよらな対象物の形状に対しても適底 し位置を決定する．義手においてもこのよらに被雑な 形状の対象物を握りまたは摆む場合に，指か接触する 位配開倸を，対象物の形状に台せて行ならことができ れば安定した把握が行なえる。このような対象物に指 の位置を適応させることをなして機構と呼ぶことに する。

プロトタイプーIでは WIME HAND を基礎とし てなじみ機構を加えリンク機構を採用して図12に 示すよらな手先とした．指の駆動は，前腕部の前腕回 内外の R S A に近い位置に指操作用 R S A を配置し， ワイヤで引張る方式とした，指操作のR S A を局に近 い毁固としたのは，義手全体の重心を局に近づけて， 慣性モーメントを小さくすることと油区回路を短くす ることおよび手掌部が型になり外観上好ましいから である. 手首の背屈のR S A 、 因12の右側の位置に 示すとおりである.

指操作R S Aからワイヤに伝えられた力住，四12に 示す $\mathrm{B}$ を支点として、リンク $\overline{\mathrm{AB}}$ を前腕侧に引張る。

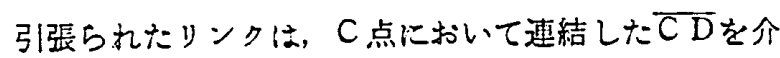
してリンク $\overline{\mathrm{EF}}$ を引き指の閉しる种作か始まる。指の 開く動作はバネの復元力による.指のなじ機輠につ

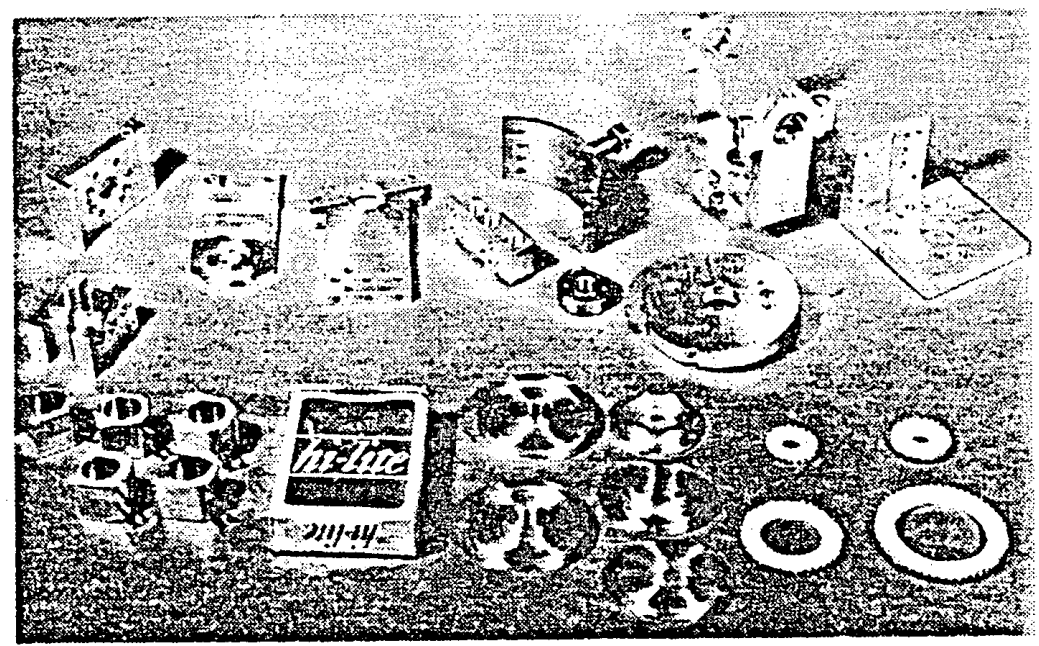

因11部品因 

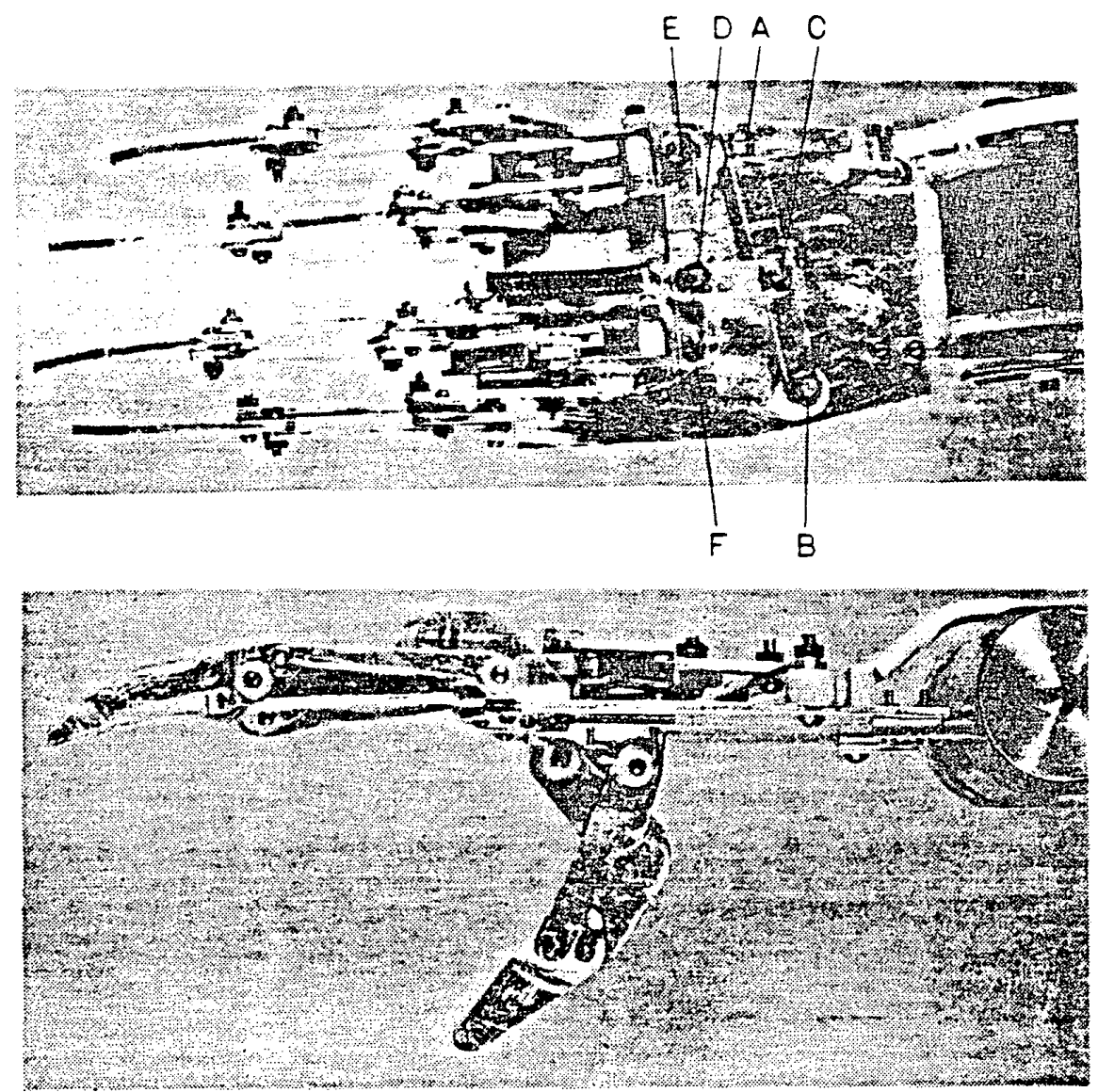

图 12 手掌部の满造

いて説明する、親指を除いた 4 指を人さし指・中指 （I群），薬指・小指（I群）の2群とする，I群は親

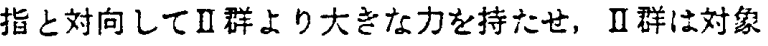
物になしむ程度の力とした：このため $\overline{\mathrm{DF}} と \overline{\mathrm{DE}}$ の距 離比を 6 ：13としてI群に大きな力を配分するように した．仮に対象物に人さし指が接触するとF点を軸と して中指がさらに閉じ，接触するとF点は止まり，さ らにE点の動作が続けられる．E点に接繶した群の 2 指もI群の動作と同じよ5に動き，対象物に接触し て動作を完了する・それでれの群の 2 指の位圈の进い によるFおよびE点での回枟による指の㮖方向人のず れは板バで逃がしている.手掌部の材料はジニラル ミンと各軸受には，摩擦を小さくするためデルリンを 採用した。

\section{5. 試作結 果}

\section{1 アクチュエータの評価}

R S A 単体の周波数応答を求め R S A の特性を調べ る.むた， R S A 入力軸駆動にDCモー夕を用いた $\mathrm{R}$
S A - D Cモータ系の周波数応答を求めて，两者の比 較を行なった。この結果よりRＳA入力軸駆動用とし てDCモータが適当であるかを調べた。

四13に特出試駼装圆とブロック図およびボード線図 を示した。

R S A 単体の周波数応答は，速い動きにも追従し良 好であったが，DCモータを台めた系の周波数応答を みると0.2 Hz 付近からゲインの低下が始むり，位相は

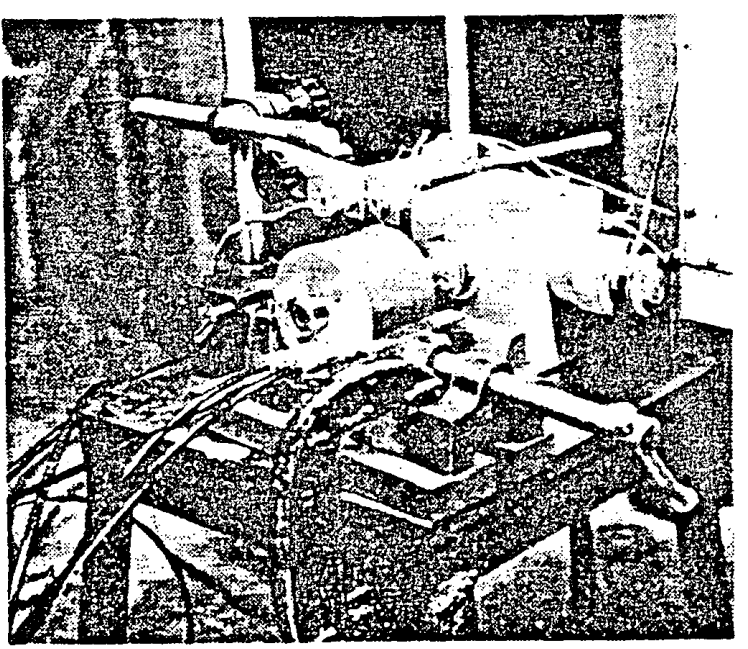

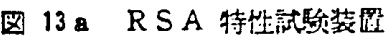




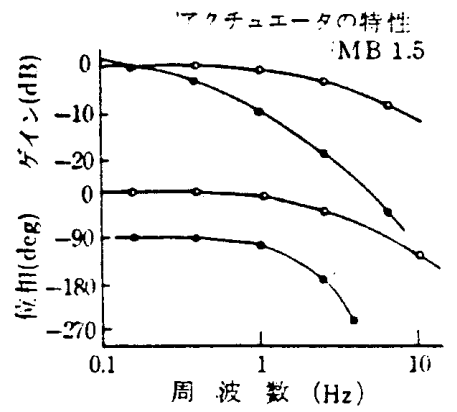

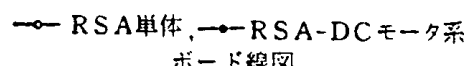

因 13b RSAの特任試駼放よび結果

低周波塔でも90度以上常に幄れていて，高周波域では 大きく湿れる。これは程分要絜による位相の 90 度幄 れ，減速機の貫性，ハックラッシ，テルトのたわみや 伸びによるゲインの低下である，位相遅れをなくすに は、この系にもら一度フィードハックをか付て，位相 進み要菜:よっって補穔しなければならない。ゲイン低 下の大きな理由:，減速機の貫性によるのでDCモー タの低速, 高トルクの機種を選定することにより, 減 速比の小さな減速機によってゲインの低下を防ぐこと ができる.

\section{2 本体の評価}

義手の評価を行なら場台の評洒基集は，たいへんむ ずかしい問題である。理想としては人問の手と同じよ

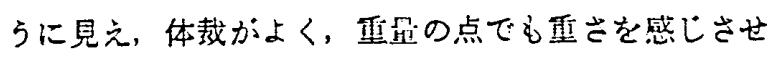
ず，機能も人問の手と同じよ5にあって耐久性があ九 ばよいしかし，これたけでは充分でなく，人間の体 にとりつ!たたりとりはずしたりすることが筒単で， 保守の面でも容易であり，信頼性のあることが必要で ある。

プロトタイプーIの本体の評洒も以上の点に留意し て進めることにする。

人間の骨に相当するFR P の梁は，強眼的には十分 な材料であり，油路の加工性も容易で，作製後梁の油 もれの試験を行ない,上腕, 前腕ともに70( $\left.\mathrm{kg} / \mathrm{cm}^{2}\right)$ で 油のむれやにしみはなかった。 シュラルミンの梁は、

重量を少なくするため必要最小限の寸法にして加工 し、軽くすることができた。油路を羕手の構造体と一 体化したことは，チニーブニネクターなどを使用しな いためシールが容易になった。油路を外部に配管する ことは，莪手の関節が功くたびに配管系に㱛しれ，た えみが繰り返されるのでよい方法ではない。
R S A の配置は，窃の全体の形から考えた場台よい 配固になったと思礼る。.とくに，肩の 3 個のR S A を人間の肩のよらに（洋服を着た場台一部分でもふく らむことのない）配置できたことは，使用者が竫手を 使用する条件につながると思ら。むた，義手の動力消 帮を少なくするためにR S A を有になるべく近い配㯰 にすることができた，指操作のR S A を前腕部に配置 することにより，手掌部の形状が人間の手に近い形と なった。

プロトタイプーIの問題点は, 義手の全重量が $4 \mathrm{~kg}$ になったことである．重量の部品に対する比率では， $60 \%$ R S A の重量で今後R S A の軽量化が檥手の実 用化の大きな間題とならら。

\section{3 埾手の動作評価}

将来，莪手の制御は管電によって行ならことを目的 としていらがプロトタイプーIでは動作評価として, スイッチによる ON-OFFにより義手を勘作させた。

自由度の期圈を人間の腕に汇近い配固としたことに より，人間の腕の動きに似せることができた，局の3 自由度の回転中心聑を台せることにより，人間の肩の ボールショイント（人間の肩関節は完全な球ではない がに近い動きをすることができたす心，肩と时の 回転中心軸を常に平行に圆くことにより，肩一肘一手 掌部が二次元平面内で動作することになり，将来の筋 電による制御を容易にした。手掌部はリンク機模によ り，人間の指の勁きに似ざせるとともに，なしみ機满 を採用し，対象物を安定した状態で把握することがで きたＲＳAの㐫答性は唖九，今後の軽量化により茷 手への利用は十分考えられるアクチュニータである。 入力軸の駆勳法については5.1で記したよ5に，R S A - DCモータ禾のゲインの低下，位相暒れについて 
考虑しなければならない。

\section{6. むすび}

現在の義手の使用夷㷫を見る時，機能をもたない外

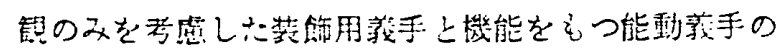

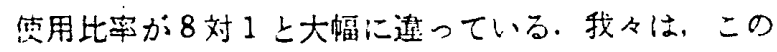
比率に目を向けなけれ:ざならない，義手は形が人間の 手に似ていることが必要であり，重量つ点では臀和感 がなく一体感をむたせるよらな軽いものでなければな らない，機能の面でも人閏の手上同しょうに動き故障 方ないこ上である。

プロトタイプー1は，浮手の奏用化のための第一步 である、機能、制御性の点で今後の研究によい资料が できたと思っている，しかし，买用化のためには多く の問題が残っている. とくに重量の点では，今後軽量 化を図り，場合によっては何らかの方法でアクチニニ 一タを少なくして,一つのアクチュエータで数数個の 自由度を動作させる必要があろう。また，各関節の動 作をよく解明し種頪の翼なったアクチニエータを使用 することも考えられる・岕らに，駆動源として人問の 身体の遊んでいる動きを何らかの方法で，䔉手の関節 に云えることも有効な方法であうら。
おわりに，R S A の製作に尽力いたたいた三菱金属 株式会社油生機器開発チームの省田氏，今永氏に深く 感謝致します。また，FR P 梁の製作で助言をいた代 心太機械技術矿究所材料工学部祆料物性課の島村課 舆，野口技官にお礼を它し上げま一。

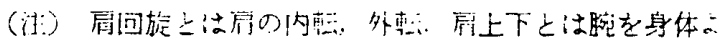

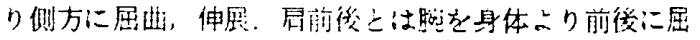
曲，伸展。以上のよう:仮称し定挛する。

\section{黄考文献}

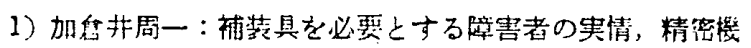
械, Vol. 40, No. 1, 1974

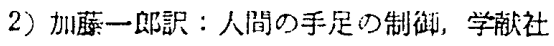

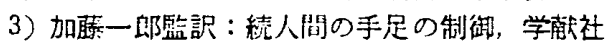

4) バイオメカニズん学会䌮: ハイイォカニズム2, 東京大 学蛙版会

5）加藤一郎：新しい義手，先端技衍総説，Vol.1，No.21， 昭和446年

6）尾畹尘太郎，中野器二：口ボットの制㓩技術，譏械の研 究, Vol.26, No.9-12, 1974

7) 加藤一䬦, 市川洌, 谷江和堆: 人工の手足, 電子涌信学 会誌, Vol.55, No.11, 昭47

8）児玉俊夫：義手，医学㶳院

9) 谷江和较，加藤一郎：人工の手の現状，機械の研究， Vol. 26, No. 1, 1974

10）加藤一郎：動力義肢，日本機械学会誌，第75卷，第 636 号, 昭和47年

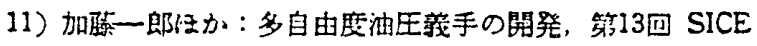

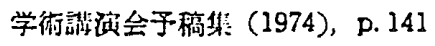



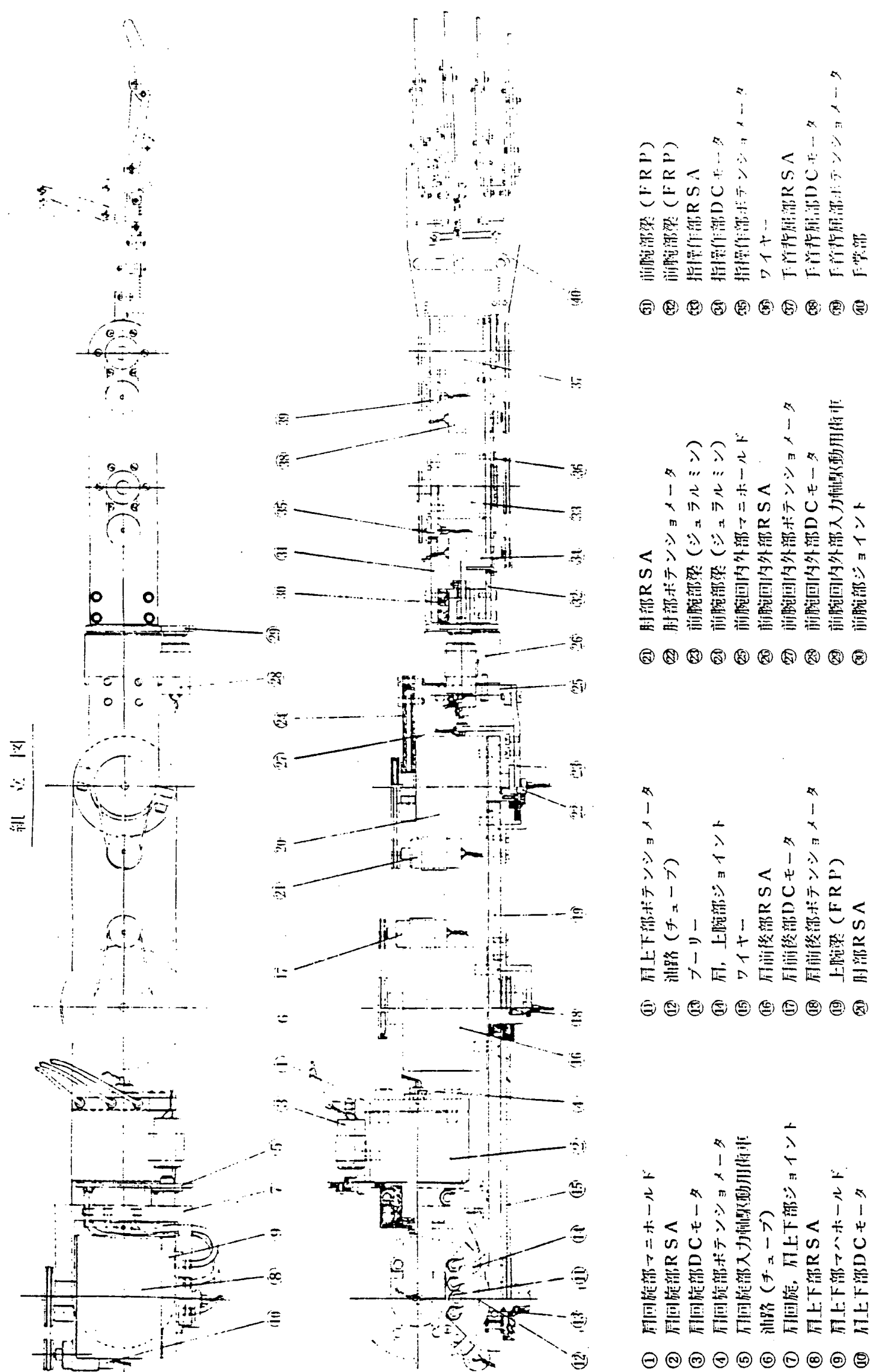

$\Leftrightarrow \Theta \Theta \Theta \Theta \Theta \Theta$

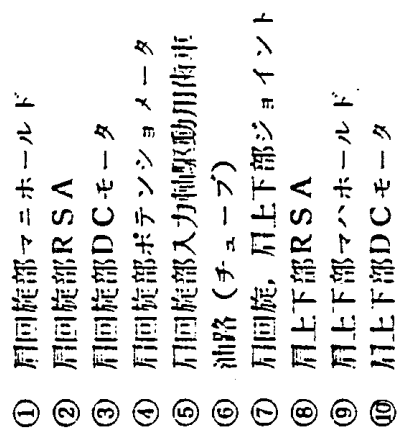

